\title{
KORSZERŰ MEGOLDÁS A FOGASKEREKEK PROFILJÁNAK PONTOS MÉRÉSÉRE
}

\section{A NOVEL SOLUTION FOR PRECISION MEASURING OF GEAR TOOH PROFILE}

\author{
Ajj Tamás-Ferenc \\ SC DSU MUREȘ S.R.L., Cím: 547530, Románia, Marosszentgyörgy, Mezögazdász \\ utca,16/B szám;Telefon / Fax: +40-265-254132, tamas.ajj@nituri.ro
}

\begin{abstract}
This paper presents the first pillar of a scientific research program consisting in the designing and implementing of a measuring device equipped with a HD camera. The proposed device will be able to substitute the nowadays used complicated gear controlling devices and etalons, sensible on mechanical and thermic impact. The proposed operating principle of the equipment allows to it the necessary versatility to be suitable with the rapidly developing production technologies. Due to the peculiarities of the digital image processing, beside the classic gear parameter measurement the proposed equipment will be able to perform comparative measuring too, e.g. the monitoring of the abrasion processes on the chosen tooth surface area. The first part of the research focuses on the straight-toothed cylindrical gears.

Keywords: gear, precision, profile, measuring equipment, image processing

\section{Összefoglalás}

A dolgozat egy kutatássorozat első pillérét mutatja be, amelynek célja olyan, kamerás rendszerrel ellátott mérőkészülék tervezése és kivitelezése, amely egymagában képes helyettesíteni a napjainkban használt fogaskerék-ellenőrző eszközöket, valamint az ezekhez tartozó, kopásra és hőre egyaránt érzékeny etalonokat. Müködési elve lehetővé fogja tenni, hogy lépést tartson a rohamosan fejlödő gyártástechnológiákkal. A digitális képfeldolgozásnak köszönhetően a fogaskerék paramétereinek mérése mellett lehetőségünk lesz összehasonlító mérések elvégzésére is. Egy lehetséges alkalmazást a fogoldal kiválasztott területein végezendő összehasonlító kopásvizsgálatban látunk. A kutatás első megközelítésben az egyenes fogazatú hengeres fogaskerekekkel foglalkozik.
\end{abstract}

Kulcsszavak: fogaskerék, pontosság, profil, mérökészülék, képfeldolgozás

\section{Bevezetés}

A gyártástechnológia fejlődésének mindenkori következménye a termelékenység növekedésében is megnyilvánul. A gyártástudomány kezdeteitől világossá vált, hogy a technológiának és a fejlesztésnek nélkülöz- hetetlen eleme a mérés, valamint a mérés kiértékelése, ugyanis ezek a folyamatok szolgáltatják az információt a gyártásparaméterek pillanatnyi állapotáról, illetve az alkalmazott technológia hatékonyságáról. Minél pontosabb adatokat tudunk mérni, 
annál pontosabb információval tudunk szolgálni a gyártás tulajdonságairól. A jól müködő minőségirányítási rendszerben szükséges ezen adatok visszavezethetöségét, nyomon követhetőségét is biztosítani. Szükségessé válik egy olyan mérési eljárás kifejlesztése, amely gyors, precíz, egyszerü és az általa szolgáltatott eredmények menthetőek és visszakereshetőek.

A digitális kamerák elterjedésének köszönhetően új lehetőségek nyíltak a gyártási paraméterek mérésére és ellenőrzésére. A gyorsaság és pontosság mellett a digitalizált kép alapján létrehozott mérési paraméterek (eredmények) könnyen menthetőek, kiértékelhetőek, és egy megadott tárhelyről könynyen visszakereshetőek.

A dolgozatban az egyenes fogú hengeres fogaskerék paramétereinek a méréseire keresem a választ digitális képfeldolgozás felhasználásával.

\section{Az egyenes fogazatú hengeres fogaskerék jellegzetes hibái}

A fogaskerekek gyártása során jelentkező hibák mindegyike a kapcsolódás alaptörvényének sérülését idézi elő. A kapcsolódás alaptörvénye értelmében az érintkező fogprofilfelületek alakjainak biztosítaniuk kell a megfelelő kapcsolódást, valamint az áttétel állandóságát:

$$
i_{12}=\frac{\omega_{1}}{\omega_{2}}=\text { állandó }
$$

A kapcsolódás csakis akkor valósulhat meg, ha a profilmerölegesek a föponton haladnak át (Willis tétele), az áttétel állandóságának, állandó tengelytáv mellett, az a feltétele, hogy a hajtás centroidái körök legyenek. Ebben áll a klasszikus, Klingelnberg-féle fogaskerék-profilmérő készülék müködési elve.

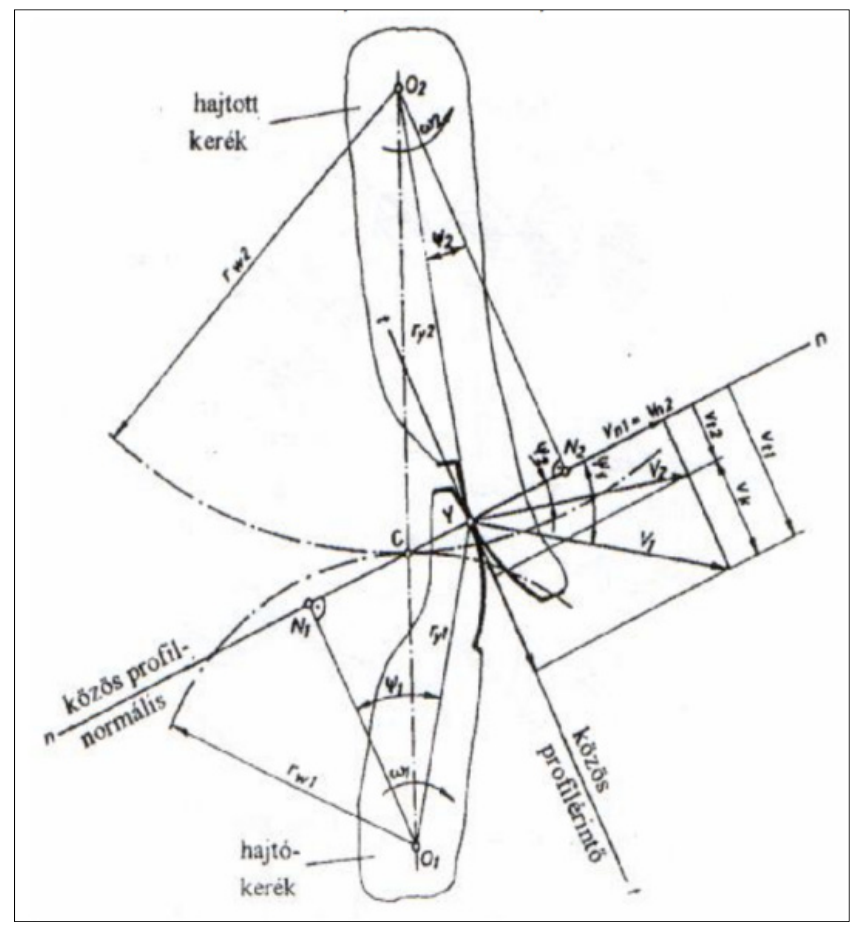

1. ábra. A kapcsolódás alaptörvénye [1] 
A kapcsolódást több paraméter is befolyásolhatja, amelyek egyaránt lehetnek a gyártás vagy a tervezés következményei. Jelen közleményben a mérhető és a gyártási hibáknak tulajdonítható paramétereket emeljük ki.

A fogaskerék-gyártásban széles körben használt az evolvens fogprofil. Több fogprofil-kialakító eljárást ismerünk. A numerikus vezérlésü köszörügépek (amelyeken számítógépes vezérléssel történik a köszörükorong-profilozás is) újra időszerüvé tették az alakköszörülést. A lefejtő eljárások viszont, különösen a lécburkolású szerszámmal történő lefejtés, semmivel sem helyettesítők adott pontossági követelményeken felül. A gyártandó kerék osztókörén csúszásmentesen legördítjük a szerszám osztóvonalát, tehát a fogaskerék profilját a fogazó szerszám profilja és ennek a gyártott kerék forgásával összehangolt szakaszos vagy folytonos elmozdulása határozza meg. Belátható, hogy a fogprofilhiba a fogazó szerszám profilhibájának, a szerszám sajátos osztáshibáinak, a szerszámgép kinematikai hibáinak és a fogazott alkatrész tájolási hibájának a következménye. Az első két, a szerszámhoz kapcsolódó hiba szisztematikus, míg a szerszámgéphez kötött hibák sztochasztikus jellegüek. A mérőkészüléken, akár a gyártórendszerben, a tájolási és a kinematikai hiba egyaránt jelen van. A felsorolt hibák hanyagolása maga után vonja a gyártott hajtás áttételi arányának lüktetését, a müködés közbeni zajokat, magas kopásokat s a fogaskerekek idő előtti tönkremenetelét.

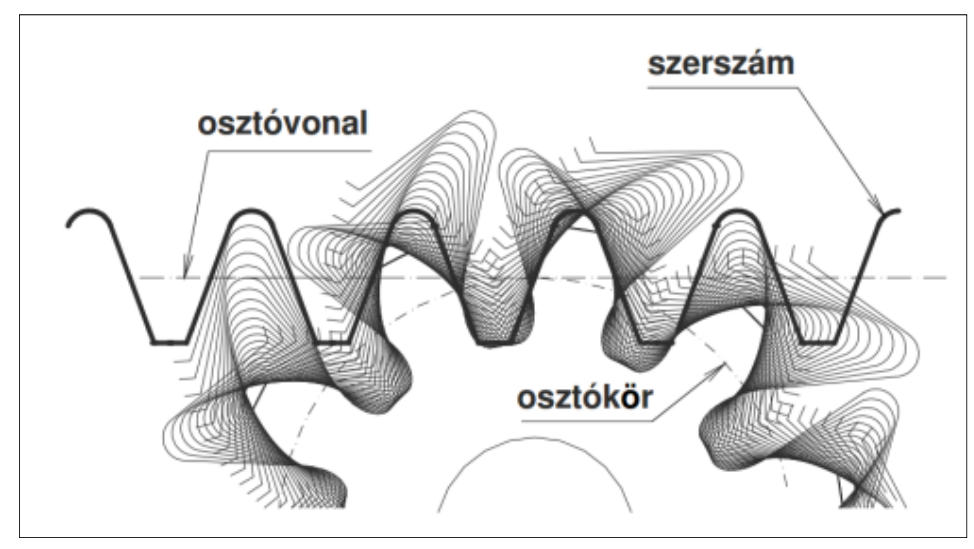

2. ábra. A fogasléces lefejtés jellegzetes görbéi [2]

\subsection{A fogprofilhiba}

Napjainkban a hengeres evolvens fogaskerekek profilhibájának mérése egyprofilos legördülő készüléken történik (Klingelnberg mérőkészülék), amely a bázishoz képest fixpontos tapintó segítségével rajzolja ki a profildiagramot, miközben a fogaskerék számított alapkörével gördül le a mérőgépállványhoz képest rögzített helyzetű alapegyenesen. A mérőmüszer mérési elve az evolvensgörbe álló egyenessel való elméleti generálásának elvét kölcsönzi. A mérési diagramon megjelenő hullámok nagysága arányos az elméleti evolvens profiltól való eltéréssel. Innen olvasható ki a fogaskerék esetleges alapkörhibája [3], amire a foglábtól a fogfej felé haladó görbe pozitív vagy negatív irányú meredekségéből lehet következtetni. A görbére illesztett egyenes (kiegyenlítő egyenes) szögéből 
lehet következtetni az esetleges alap profilszög hibára is [3].

Azokban az esetekben, ahol a fogprofilt nem lehet vagy túl költséges lenne mérni, úgynevezett hordképvizsgálatot alkalmaznak. Ez esetben egy lassan száradó speciális festékkel kenik be a mérendő fogaskerék fogait, majd terhelés nélkül mesterkerékkel gördítik össze. A legördülés következtében a mesterkerék fogfelületére tapadó festékfolt kiterjedése és helyzete alapján állapítják meg a vizsgálandó fogprofil minőségét. Ebben az esetben a kiértékelést inkább a tapasztalat, mintsem a numerikus értékek határozzák meg.

\subsection{Az osztáshiba}

Osztásnak nevezzük két egymás követő fogfelület homológ pontjainak köríven mért távolságát. Abban az esetben, ha az osztást az alapkörön mérjük, alaposztásról, ha az osztókörön mérjük, osztóköri osztásról beszélünk. Az osztáshiba nem más, mint a valóságban mért osztás eltérése az elméleti osztástól. Igen nagy valószínüséggel okozhatja az osztáshibát a fogazó szerszámgép előtoló- és osztóláncának a meghibásodása vagy kopása.

Az osztás mérésére több eljárást fejlesztettek ki. Az első, legegyszerübb abban áll, hogy két, egymás melletti fogárokba köszörült csapokat helyezünk, és megmérjük a két henger közötti (vagy ezeken átívelő) távolságot, amiből kiszámítjuk a szögosztást, majd pedig az osztóköri osztást [6]. Ez a módszer viszonylag pontatlan, mivel a méréshez hozzáadódik a fogfelületi hiba is.

A második eljárás az osztóköri osztásmérés-elmozdulás mérőkészülék segítségére alapszik. Digitális vagy mechanikus tapintók segítségével lokalizáljuk az egymás után következő fogakon a homológ pontokat, így állapítjuk meg a valós osztásértéket. Ezután két szomszédos osztás különbségét használjuk fel. Az eredmények felhasználásával mind az összegzett, mind az egyszerü osztáshiba-diagramot felrajzolhatjuk.
A harmadik eljárás a Maag-féle mérőkészülék sajátossága. A készülék a fogaskeréknek azt a tulajdonságát használja fel, hogy az alapkörön található két, azonos irányú, egymást követő evolvens normális irányban mért távolsága megegyezik a két evolvens közötti alapköri ív méretével, tehát az eljárás az alaposztás hibát méri.

\subsection{Többfogméret mérés (Wildhaber)}

A többfogméret $W$ jelét Wildhaber osztrák mérnök nevéről kapta. Az eljárás lényege abban áll, hogy két ellentétes irányú evolvens közötti, az alapkört érintő egyenes szakasz hossza nem változik, ha közben ez az alapkörön legördül. A $W$ mért értékeinek ingadozása a radiális ütésre és a fogvastagság-ingadozásra egyaránt utal.

A többfogméretet a fogaskerék elöírt türésosztályának megfelelően a

$$
\left.W(k)_{-\left(E_{w s}\right.}^{-E_{w s}}+T_{w}\right)
$$

képlettel adják meg külső fogazatra, ahol $E_{w s}$ a többfogméret hézagmentes névleges értékének minimális eltérése, $T_{w}$ a radiális ütés türése.

A fennebb említett eljárások mindegyike külön speciális mérőkészüléket igényel, amelyek használata sok türelmet és időt követel. A mérési pontosság emberfüggő, valamint $R \& R$ elemzést is igényel.

\subsection{A hengeres fogaskerekek pontos- sági besorolása}

A hengeres fogaskerekek geometriai elemeinek számítására ismert képletek állnak rendelkezésre [6]. A szabványos modul és a szükséges áttételi arány, valamint a hajtókerék fogszámának kijelölése után [7] megválasztással a (2) - (18) egyenletek könnyen felírhatóak, feltételezve, hogy ismerjük a fogazószerszám paramétereit. A számítások során figyelembe kell venni az alámetszést (interferenciát), a határfogszámot, illetve a kiválasztott fogaskerékanyag 
tulajdonságaiból adódó szilárdságtani méretezést. Jelen dolgozat a fogaskerék geometriájával kapcsolatos.

A gyártás során bármely hossz- vagy szögméret sztochasztikus jelleget ölt. Emiatt ezeket a paramétereket mérnünk kell, megbizonyosodva arról, hogy a fogaskerék a kívánt pontossági osztályba esik vagy sem. [5]. A fogaskerekeket 12 pontossági osztályba sorolják az egyes hibafajták türései alapján:

- 1, 2 pontossági fokozat: a mai technológiával még nem gyártható;

-3, 4 pontossági fokozat: mesterkerekek pontossága;

$-5,6$ pontossági fokozat: köszörüléssel gyártható kerekek;

-7, 8, 9 pontossági fokozat: általános gépszerkezet fogaskerekei;

-10, 11 pontossági fokozat: forgácsolással, nagyolva gyártható;

- 12 pontossági fokozat: már öntve vagy kovácsolva is gyártható.

A türések az osztályoknak megfelelően táblázatban vannak összesítve [2].

Amint a hengeres fogaskerekek pontossági szabványaiból belátható, igen nagy számú paraméter méretvizsgálata szükséges a helyes besoroláshoz. A mesterkerekeket, kalibereket használó eljárások nem méretfüggetlenek; modulonként több etalont kell legyártani vagy megvásárolni, ami a gyártási költségeket a pontossággal exponenciálisan növeli. Az ember mint hibaforrás kiküszöbölhetetlen a klasszikus eszközökkel végzett mérések esetében. A klaszszikus fogaskerék-ellenőrző készülékek és berendezések müveleti alapideje is meglehetősen nagy, ami a gyártási folyamat taktusát korlátozza. A fent ismertetett érvek és tények tükrében belátható, hogy szükségszerüvé válik egy olyan mérőeszközt kifejleszteni, amely a jelen hátrányokat kiküszöböli.

\section{Fogaskerékmérés digitális kép- feldolgozással}

A digitális képfeldolgozással való mérés hasonló egy projektorral való méréshez, azzal a különbséggel, hogy a kapott képkockák (pixelek) mindegyikéhez hozzá lehet férni, saját koordinátáik vannak, müveleteket lehet velük végezni, egyenként vagy akár globálisan is.

Minden képkockának 3 paramétere van, ami nem más, mint a föszínek (RGB) értékei. Ezekből a paraméterekből, ha globálisan kezeljük, következtetéseket lehet levonni egy adott céltárgy helyzetéről, nagyságáról, tulajdonságairól.

\subsection{A probléma felvetése}

A feladat megoldásának kulcsa abban áll, hogy milyen képszüréstechnikákat kell alkalmazni ahhoz, hogy a keresési algoritmust ne zavarja a változó külső fényintenzitás, illetve más, a mérési környezetben jelentkező zavaró tényező. A mérési folyamatot a következő elvi részekre kell bontani:

- a céltárgy, jelen esetben a fogaskerék, akár feldolgozott, akár élőképen (kamera elé helyezett céltárgy) megtalálása a képsíkon;

- a céltárgy szignifikáns részeinek, azok helyzetének, elfordulásainak felismerése;

- a szignifikáns képkockák geometriai elemekké való alakítása;

- az elméletileg kiszámítható geometriai entitások ponthalmazainak lokalizálása koordináták felírása és mentése;

- a szignifikáns képkockák és az ideális képkockahelyek távolságának számítása;

- a különbségek átalakítása szabványosított méretekké és ezek kiértékelése.

A feladat adatai a fogaskerék konstruktív adatai és a pontossági osztálynak megfelelő türések.

Mérés esetében nem a gyorsaság a fó cél, hanem a pontosság. Meg kell jegyezni, hogy a javasolt módszer esetében az ösz- 
szegzett mérési idő másodperceket tehet ki. A maximális tervezett idő 4-5 másodperc, ami lényegesen kevesebb bármely kiválasztott, jelenleg használt eljárás mérési időigényénél. A pontosságnak a javasolt mérési módszer esetében kizárólag a kamera felbontása és a választott kamerafókuszpozicionáló szerkezet sajátosságai szabnak határt.

\subsection{A javasolt mérőkészülék szerke- zeti felépítése}

A mérőkészülék szerkezeti felépítését a 4. ábra szemlélteti. Ahhoz, hogy mérni tudjunk, szükséges kiválasztanunk egy megfelelö felbontással és gyorsasággal rendelkező kamerát (1). A piacon található számos típus közül választásunk egy Microsoft LifeCamStudio HD kamerára esett, melynek paraméterei a következők: 5 megapixeles CMOS szenzor, $1920 \times 1080$ pixel maximális felbontás, 30fps képfrissítés másodpercenként, $75^{\circ}$ átlós látómező. A kamera beállításai programozhatóak élő kapcsolatban is.

Vannak olyan külső zavaró tényezők, amelyeket a programból nem tudunk kiiktatni, mint például a vizsgált felületekröl visszaverödő intenzív fény.

Emiatt szükségessé válik a kamera CPL polárszürővel való felszerelése (2), amely kiküszöböli az előbb említett zavaró hatást.

Ahhoz, hogy a kereső algoritmus el tudja különíteni a (3)-as képtérbe helyezett (4)es fogaskereket, a készülék asztala (5) fényáteresztő anyagból kell készüljön, amit a (6) változtatható háttérvilágítás világít meg. A fogaskerék nem engedi át a fényt, ezért jól elhatárolódik környezetétől.

A készülék rendkívül fontos része a (7) kameramozgató szerkezet. Mindenekelőtt ahhoz, hogy a kamera megfelelően tudjon mérni, kalibrálni kell egy megfelelően felvett fókuszpontra.

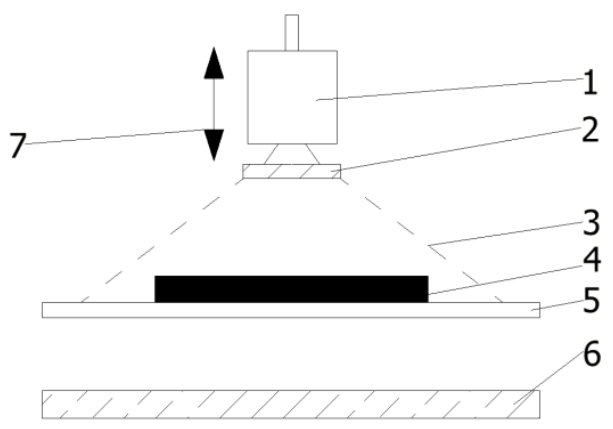

4. ábra. Mérökészülék szerkezeti felépitése

Ez történhet akár egy mikrométer vagy egy tolómérő etalonnal is, mivel itt egy átmérőkalibrációt tervezek. Kalibráció után, amennyiben változtatom a fókuszpontot, a rendszer automatikusan változtatja arányosan a kalibrációs együtthatót is.

\subsection{A vizsgálandó kép előkészítése}

A kamera által szolgáltatott kép önmagában nem alkalmas a kereső algoritmusok fogadására. Megfelelően elő kell ezért készíteni.

Mivel a kamera képe eredetileg színes, ami megnövelné az igényelt számítási kapacitást, első körben a kapott képet feketefehér állapotra kell alakítani.

A következő lépésben a képen fellelhető zajokat kell eltávolítani. E célra átlagoló szürő vagy Gauss-szürő alkalmazható. A kedvezőbb eredményt adó megoldást választjuk.

A harmadik lépésben a kamerára felszerelt CPL szürő által átengedett maradék fényzavarokat kell megszüntetni. Itt a legjobb megoldást akkor kapjuk, ha két különböző $\sigma$ paraméterrel rendelkező Gaussszürővel megszürt képet vonunk ki egymásból. Ezt Gauss-skálázásnak is nevezik. Mivel a képen található forma méretben kissé módosul, de a jellemzői megmaradnak, s a zavaroktól is mentes, a keresést a kapott képen végezzük el, míg a többi müveletet az eredeti szürt képen. 


\subsection{Jellemző pontok kinyerése}

A legjobb megoldás a jellemző pontok kinyerésére a sarokpontkeresési algoritmusok felhasználása, amely lehet Harris- vagy gyors sarokpontkeresési algoritmus. Első körben a gyors sarokpontkeresési algoritmust fogjuk alkalmazni. Tapasztalataink alapján a megfelelő beállitással a talált pontok stabilak, ellentétben a Harris keresési algoritmussal, kevesebb a számítási igénye, $\mathrm{s}$ a találatok száma is jóval magasabb. Itt az a legfontosabb, hogy minél több jellemző pontot tudjunk kinyerni a fogaskerékről, amelyek tovább osztályozódnak különbözö szürési eljárásoknak köszönhetően. A Harris sarokpontkereső algoritmus túl érzékeny. Amennyiben a paramétereinek a változtatásával elérjük, hogy az előzőekben nem aktív régiókban is találatokat szerezzen, túlságosan megnő a számítási kapacitás a gradiensszámítások miatt, valamint igen sok téves találatot térít vissza.

\subsection{A kinyert jellemző pontok osztá- lyozása}

Ez a rész tekinthető a legnehezebb feladatnak, amelynél még igen sok kutatás, fejlesztés szükséges. A kapott pontoknak megvan a képi koordinátája. A pont környezete alapján ki kell értékelnünk, hogy a fogaskerék mely részéhez is tartozik. Erre a legjobb megoldás a neuronháló alkalmazása. Mint ismert, a háló képes osztályozni, s egy jól megalkotott tanítóhalmaz megtanulása után képes megfelelő döntést hozni akkor is, ha a bemeneti kép kissé „torzult”. Ebben az esetben a neuronháló bemenete az illető pont, valamit az előre meghatározott környezeti pontok értékei, kimenete pedig a keresett rész indexe.

Ebben az esetben több probléma is felléphet. A háló rugalmas, de nem a végtelenségig. Probléma lép fel, ha a bemeneti kép iránya túlságosan el van fordulva a tanítóhalmazban szereplö elemektöl. Tehát ebben az esetben kell tudjunk következtetni, hogy a fogaskerék azon eleme, amit vizsgálunk, milyen irányban is lehet elfordulva, mivel 0-360 fokos tartományban bármilyen irányon illeszkedhet. Az egyik megoldás erre, mivel a fogaskereket egy szimmetrikus testnek tekintjük. Elsőként a képet egy direkt Fourier-transzformációval szürni kell, máskülönben hibás értéket kaphatunk. Ezek után kiszámolhatjuk a gradiens hisztogramját. A kapott görbe csúcsai megadják a fogaskerék szimmetriatengelyeinek a szögeit. Amennyiben a központhoz (ami nem más, mint a képi súlypont) koordinátatengelyeket rendelünk, s azt vesszük nullpontnak, a vizsgált pontok helyzetéből meg tudjuk határozni, hogy az illető zóna hogyan van elfordulva. Amennyiben a fogaskerék reteszhoronnyal rendelkezik, azt a képröl el kell távolítani, mert zavart okozhat a szimmetriában. Ez csak egy megoldásjavaslat, ami ellenőrzésre szorul, mivel a szimmetriatengelyek több állapotot is felvehetnek, ami zavaró.

A második probléma a különböző méretü fogaskerekek vizsgálata. Kényelmetlen lenne, ha az összes fogaskeréktípust meg kellene tanítani ahhoz, hogy a háló felismerje a különböző részeit. Tehát ebben az esetben a kicsinyítést, nagyítást kell alkalmazni egy előre megadott bázisméretre. Az algoritmusnak fel kell ismernie a fogaskerék méretbeli eltérését a bázismérettől, majd ennek függvényében a megfelelő méretre hozza az illető fogaskerék képét.

\subsection{A mérés menete}

A mérés lényegében egy ellenőrzés. Az algoritmus kiszámolja először a fogaskerék összes névleges paraméterét a bemenetek alapján, illetve a méretekhez tartozó szórásokat. A következő lépésben a már feltérképezett fogaskerék segítségével az algoritmus kiszámolja a valós méreteket, majd ezek a méretek összehasonlításra kerülnek az elméleti követelményekkel. A kiértékelés azonnal végbemegy. 


\subsection{A programfelület}

Annak érdekében, hogy a mérőkészülékhez egy kezelőpanel is társuljon, a vezérlö, kereső, mérő algoritmusok megírásához C\# környezetet választunk. Az algoritmus a kezelöpanelra ad visszaigazolást a pillanatnyi állapotokról. A mérési eredmények is ide kerülnek kijelzésre. A tanítás, illetve vezérlés szintén ezen a felületen kap helyet.

\section{Következtetések}

A vázolt megoldás olyan számítógéppel segített mérési eljárást sejtet, amely a klaszszikus mérőrendszerekkel szemben kevésbé költséges, rugalmasabb és hatékonyabb.

\section{Szakirodalmi hivatkozások}

[1] Stampfer, M.: Fogaskerékhajtások, Pécsi Tudományegyetem, Pécs, 2004.

[2] Német, G.: A fogaskerékhajtásról röviden II. $F M K$. BSc. hallgatói részére (tananyag kiegészitö segédlet), Sopron, 2007.

[3] Groma, I.: Térbeli fogazott hajtópárok gyártásgeometriai viszonyainak matematikai model-

lezése és szimulációja. PhD értekezés, Budapest, 2010.

[4] Szendrő, P.: Gépelemek., TAMOP 4.2.5 pályázat könyvei. Mezőgazda Kiadó.

[5] Szeniczei, L.: Általános fogazás, Nehézipari Müszaki Könyvkiadó, Budapest, 1958. 